\title{
EHMTI-0033. The phosphodiesterase 3 inhibitor cilostazol induces migraine-like attacks via cAMP increase
}

\author{
G Song ${ }^{*}$, J Olesen, M Ashina \\ From 4th European Headache and Migraine Trust International Congress: EHMTIC 2014 \\ Copenhagen, Denmark. 18-21 September 2014
}

\section{Introduction}

The initiating mechanisms of migraine attacks are very complex but may involve the cyclic adenosine 3',5'-monophosphate (cAMP) signaling pathway. It is unknown whether intracellular cAMP accumulation induces migraine attacks.

\section{Aim}

To investigate whether administration of cilostazol, which causes cAMP accumulation, may induce migraine attacks.

\section{Methods}

We included 14 migraine patients without aura in a double-blinded, placebo-controlled crossover study. All participants received oral cilostazol or placebo on two separate days. We recorded migraine headache characteristics and associated symptoms using a questionnaire.

\section{Results}

Cilostazol induced delayed migraine-like attacks in 12 patients (out of 14) compared to 2 (out of 14) patients after placebo $(\mathrm{P}=0.002)$. The median time to onset for migraine-like attacks was $6 \mathrm{~h}$ (range 3-11 h). Patients reported that the attacks mimicked their usual migraine attacks and that cilostazol induced attacks responded to their usual migraine treatment. The median time of medication intake was $6 \mathrm{~h}$ (range 4-11).

\section{Conclusions}

The present study suggests that intracellular cAMP accumulation plays a crucial role in migraine induction. This knowledge is a further step in our understanding of the intracellular pathway of migraine initiation.
No conflict of interest.

Published: 18 September 2014

\section{doi:10.1186/1129-2377-15-S1-A5}

Cite this article as: Song et al: EHMTI-0033. The phosphodiesterase 3

inhibitor cilostazol induces migraine-like attacks via cAMP increase. The Journal of Headache and Pain 2014 15(Suppl 1):A5.
Submit your manuscript to a SpringerOpen ${ }^{\circ}$ journal and benefit from:

- Convenient online submission

- Rigorous peer review

- Immediate publication on acceptance

- Open access: articles freely available online

- High visibility within the field

- Retaining the copyright to your article

Submit your next manuscript at $>$ springeropen.com

\section{SpringerOpen ${ }^{\circ}$}

C 2014 Song et al; licensee Springer. This is an Open Access article distributed under the terms of the Creative Commons Attribution License (http://creativecommons.org/licenses/by/2.0), which permits unrestricted use, distribution, and reproduction in any medium, provided the original work is properly cited. 